\title{
Leaching impacts Ni toxicity differently among soils but increases its predictability according to nitrification assay
}

\author{
Xiaofang Li • Yizong Huang • Yibing Ma • Jinwei Sun • \\ Haojie Cui
}

Received: 25 July 2009 /Accepted: 9 September 2009/Published online: 18 September 2009

(C) Springer-Verlag 2009

\begin{abstract}
Purpose Deriving toxicity thresholds through bioassays has become the scientific basis for the risk assessment of metal contamination in soils, but few studies have been reported for Ni toxicity in Chinese soils. In addition, although leaching has been recommended to increase the ecological relevance of the output of soil toxicity bioassays, its impacts on Ni threshold and soil solutions in soils remained to be shown. Therefore, in this study, 17 soils were collected throughout China and were assessed for Ni toxicity using substrate-induced nitrification (SIN) assay for both un-leached and leached treatments. Meanwhile, soil solutions of all Ni treatments were extracted and analyzed. This study provides information for the development of a terrestrial biotic ligand model (TBLM) for $\mathrm{Ni}$ in Chinese soils.
\end{abstract}

Responsible editor: Hailong Wang

X. Li $\cdot$ H. Cui

Key Lab of Urban Environment and Health, Institute of Urban Environment, Chinese Academy of Sciences, Xiamen 361003, China

X. Li $\cdot$ Y. Huang $(\bowtie) \cdot$ H. Cui

Research Center for Eco-environmental Sciences,

Chinese Academy of Sciences,

Beijing 100085, China

e-mail: hyz@rcees.ac.cn

Y. Ma

Ministry of Agriculture Key Laboratory of Plant Nutrition and Nutrient Cycling, Institute of Agricultural Resources and Regional Planning, Chinese Academy of Agricultural Sciences, Beijing 100081, China

J. Sun

College of Forestry, Guangxi University,

Nanning 530001, China
Materials and methods Soils were artificially amended with $\mathrm{NiCl}_{2}$ solution to generate nominal $\mathrm{Ni}$ contamination levels, and aliquot of each $\mathrm{Ni}$ treatment was leached with artificial rain to prepare leached soil samples. All the 17 unleached and the 17 leached soils were subjected to the standard SIN protocol. A total of 816 microcosm tubes were established. Soil solution was extracted, and the solution physiochemical properties were analyzed for each $\mathrm{Ni}$ treatments. Both the total-Ni-based and the solution-Nibased median effective concentrations (EC50) in unleached soils and leached soils were calculated from dose-response curves. Free- $\mathrm{Ni}^{2+}$-based EC50 was also calculated based on solution chemical properties. Leaching effect was assessed based on these results.

Results and discussion Ni EC50 varied largely among soils for both the total-Ni-based and the solution-Ni-based EC50 in un-leached soils. In un-leached soils, the total-Ni-based EC50 values ranged from $52.8 \mathrm{mg} \mathrm{kg}^{-1}$ (Hulunber soil) to 2,385.4 $\mathrm{mg} \mathrm{kg}^{-1}$ (Wulumuqi soil), and the solution-Nibased EC50 ranged from $0.70 \mathrm{mg} \mathrm{L}^{-1}$ (Jiaxing soil) to $293.35 \mathrm{mg} \mathrm{L}^{-1}$ (Wulumuqi soil). Stepwise multiple regressions showed that soil $\mathrm{pH}$ and total $\mathrm{Ca}$ were the best predictors for the total-Ni-based EC50. Protective effects of $\mathrm{Ca}^{2+}$ and $\mathrm{Mg}^{2+}$ but not $\mathrm{H}^{+}$against $\mathrm{Ni}$ toxicity in soil solution were found. Leaching impacted Ni EC50 differently among soils, with leaching factor ranging from 0.2 (Haikou soil) to 19.7 (Hulunber soil) for the total-Ni-based EC50 and from 0.1 (Dezhou soil) to 35.7 (Jiaxing soil) for the solution-Ni-based EC50. In addition, predictability of Ni EC50 was higher in leached soils. The variations in $\mathrm{Ni}$ EC50 were in agreement with the findings in previous studies. Soil $\mathrm{pH}$ and $\mathrm{Ca}$ may play important roles in the partition of $\mathrm{Ni}$ in Chinese soils and thus impact the $\mathrm{Ni}$ toxicity. Protective effects of $\mathrm{Ca}^{2+}$ and $\mathrm{Mg}^{2+}$ in soil solutions against $\mathrm{Ni}$ toxicity may exist, but the role of $\mathrm{H}^{+}$ 
remained to be justified. The inconsistent impact of leaching on the free $\mathrm{Ni}^{2+}$ concentration at low $\mathrm{Ni}$ doses and the two competing effects of loss of salts in soil solution on Ni EC50 can partly account for the variation in leaching factor among soils.

Conclusions $\mathrm{Ni}$ toxicity varied largely among Chinese soils, and this variation can be largely explained by soil parameters. Leaching-impacted soil solution compositions and Ni EC50 values heavily. The impacts, however, were apparently different among soils. The results in this study can be used to develop a TBLM for $\mathrm{Ni}$ in Chinese soils. Furthermore, a need exists to quantitatively investigate the leaching effect on soil solution chemistry before leaching is used as a standard protocol in toxicity assays.

Keywords Leaching $\cdot \mathrm{Ni}$ toxicity $\cdot$ Nitrification assay $\cdot$ Soil . Soil solution

\section{Introduction}

Most of the current guidelines for heavy metals in soil are still based on total metal concentration; this is also the case in China (GB 15618-1995, http://www.cnemc.cn/images/ temp/aa19741f-b768-4b33-8352-3ee774599e99.pdf). However, the total concentration has been demonstrated not to be directly responsible for the exposure risk of metals to soil biota (Allen et al. 2008; Giller et al. 1998; Lofts et al. 2004; Nriagu and Pacyna 1988). Thus, there is an increasing need to incorporate toxicity tests in risk assessments and the establishment of site-specific guidelines for metals in soils (Fernandez et al. 2005).

$\mathrm{Ni}$ is an essential element for organisms, but excess $\mathrm{Ni}$ in soil can exert toxic effect on soil biota and expose indirectly risks to human beings (Allen et al. 2008; Berton et al. 2006; Fargasova 2008; Lock and Janssen 2002). Efforts have been made to investigate the $\mathrm{Ni}$ toxicity thresholds in European soils using various toxicity assays including barley root elongation (Rooney et al. 2007) and microbial assays (Oorts et al. 2006, 2007). Moreover, these resultsbased toxicity assays were used to establish a terrestrial biotic ligand model (TBLM; Thakali et al. 2006a, b), which incorporated the concepts of free ion activity model and the theory of protective cations (Allen et al. 2008; Paquin et al. 2002). TBLM has been shown to be a promising method to predict EC50 values for $\mathrm{Ni}$ in soils in less time and at lower cost. However, few of such studies have been systematically done for Ni toxicity in Chinese soils.

Presently, modeling of metal toxicity thresholds in soils largely relies on not only the method of toxicity assay but also the metal speciation and the chemo-physical environment in soil solution. Accordingly, analysis of the partition behavior of metal after addition to soil is a critical step.
Although a TBLM presented by Thakali et al. (2006a, b), on the basis of solution chemistry analysis, largely explained the variation in the solution-Ni-based EC50 in European soils, prediction of Ni EC50 in alkaline soils is still difficult (Wang et al. 2009). Therefore, it is necessary to couple the toxicity assay with a detailed investigation of the soil solution.

In addition, leaching has been recommended to increase the ecological relevance of the output of soil toxicity bioassays (Lock et al. 2006; Oorts et al. 2007). Yet, that how leaching affects $\mathrm{Ni}$-amended soil solution and $\mathrm{Ni}$ EC50 in soils remains unrevealed on a larger scale before leaching is used as a standard protocol in soil toxicity assay.

Therefore, the aims of this study were to (1) screen Ni toxicity in Chinese soils using substrate-induced nitrification (SIN) assay with the objective of generating information for the development of a TBLM for $\mathrm{Ni}$ in Chinese soils, and (2) investigate the leaching effect on Ni toxicity thresholds in soils. To this end, 17 soils were collected throughout China, and the widely used nitrification assay (Broos et al. 2005; Oorts et al. 2006; Smolders et al. 2001, 2004) was used for screening Ni toxicity in both un-leached and leached soils. In addition, soil solutions of each $\mathrm{Ni}$ treatment were analyzed.

\section{Materials and methods}

\subsection{Soils}

Seventeen uncontaminated topsoils were collected throughout China. The soils represent the major soil types, soil $\mathrm{pH}$, and organic matter content (OMC) of arable soils in China. Selected properties of the soils were listed in Table 1. The soils were air-dried and sieved through $2 \mathrm{~mm}$ mesh and then were measured for soil physicochemical properties. Briefly, soil $\mathrm{pH}$ was measured with a soil/water ratio of 1:5. Soil OMC was determined by combustion analysis (Marriott and Wander 2006). Total nitrogen content was determined as $\mathrm{N}_{2}$ by thermal conductivity detection (Matejovic 1997). Cation exchanging capacity (CEC) was measured with $1 \mathrm{M}$ ammonium chloride at $\mathrm{pH} 7.0$ after pretreatment to remove soluble salts. Soil texture was analyzed following the method of Tan (2005). Elemental concentrations were determined by inductively coupled plasma (ICP) atomic emission spectrometry (AES) or ICPmass spectrometry (MS) after dissolving with aqua regia $\left(\mathrm{HNO}_{3}: \mathrm{HCl}=1: 3\right.$; Zarcinas et al. 1996).

\subsection{Soil Ni addition and leaching}

Sieved, air-dried soil was amended with $\mathrm{NiCl}_{2}$ (Shenyang Reagent Company, China, analytical grade) solution to 


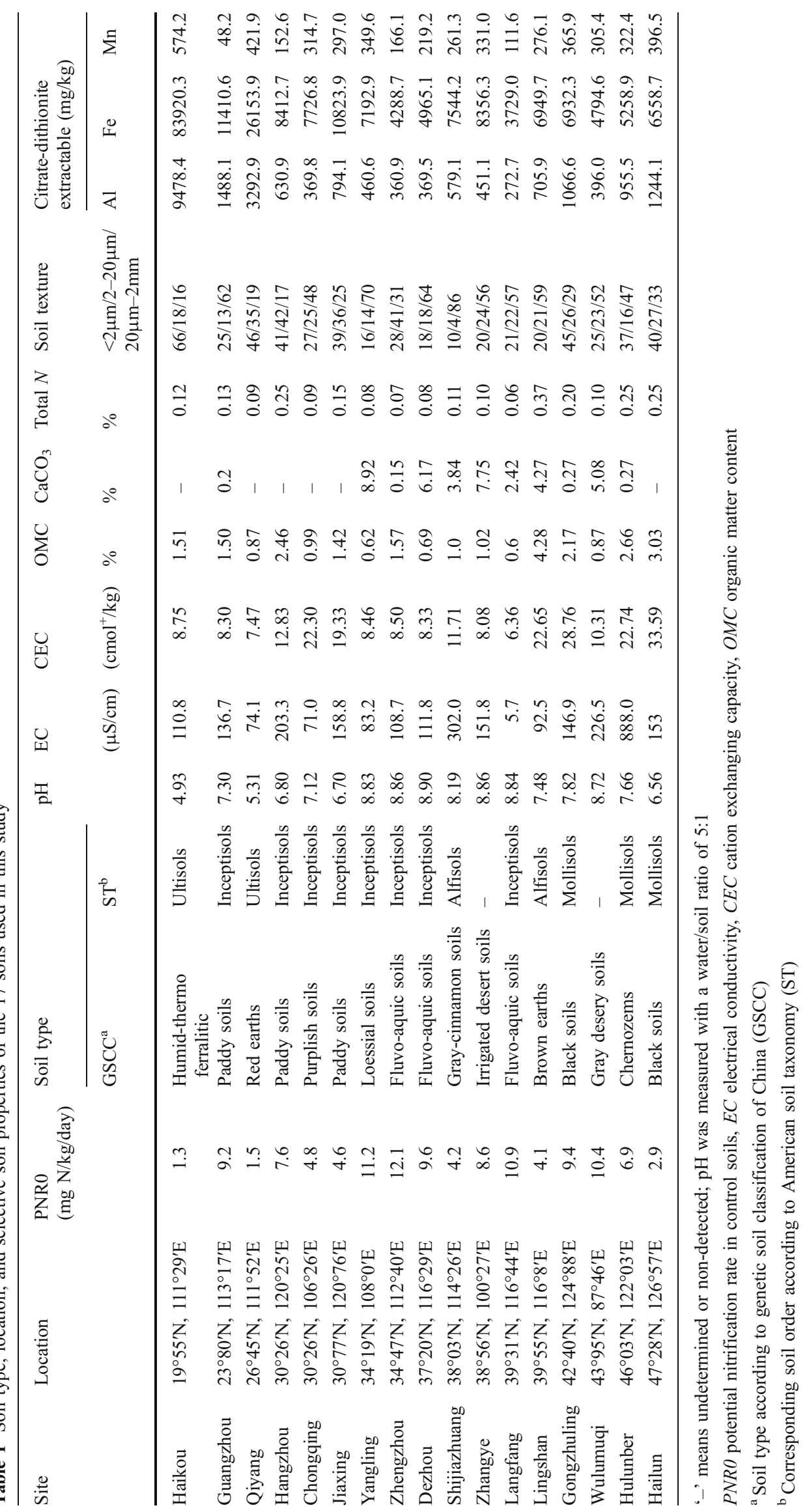


produce nominal concentrations of $37.5,75,150,300,600$, 1,200, and 2,400 $\mathrm{mg} \mathrm{Ni} \mathrm{kg}^{-1}$ dry soil for soils with $\mathrm{pH}>7$; $25,50,100,200,400,800$, and $1,600 \mathrm{mg} \mathrm{kg}^{-1}$ dry soil for soils with $\mathrm{pH}<7$; and $12.5,25,50,100,200,400$, and $800 \mathrm{mg} \mathrm{kg}^{-1}$ dry soil for soils with $\mathrm{pH}<5$. The amended soils were left to equilibrate overnight at $100 \%$ maximum water holding capacity (MWHC), then air-dried and sieved again through 2-mm mesh.

Aliquot of the freshly spiked soil was leached for each $\mathrm{Ni}$ treatment and for each soil by artificial rainwater before use. The detailed composition of the artificial rainwater and protocol for the preparation of the leached samples were as described by Oorts et al. (2007). Briefly, the soils were leached with two pore volumes of artificial rainwater $\left(\mathrm{CaCl}_{2}\right.$ $5 \times 10^{-4} \mathrm{M}, \mathrm{Ca}\left(\mathrm{NO}_{3}\right)_{2} 5 \times 10^{-4} \mathrm{M}, \mathrm{MgCl}_{2} 5 \times 10^{-4} \mathrm{M}$, $\mathrm{Na}_{2} \mathrm{SO}_{4} 10^{-4} \mathrm{M}$, and $\mathrm{KCl} 10^{-4} \mathrm{M}, \mathrm{pH}$ 5.9). Leached samples were also air-dried and sieved through 2-mm mesh. All un-leached and leached soils were stored at room temperature before use.

\subsection{Substrate-induced nitrification assay}

The un-leached and leached soils were used to establish a standard SIN assay (Oorts et al. 2006; Smolders et al. 2001, 2004). For pre-incubation, three replicates of $7 \mathrm{~g}$ amended soil for each $\mathrm{Ni}$ treatment were incubated under dark aerobic conditions at $25 \pm 2^{\circ} \mathrm{C}$ in a $50-\mathrm{ml}$ centrifuge tube maintained at $50 \pm 5 \%$ of MWHC by addition of deionized water. Totally, 816 microcosm tubes were established. After the 14-day pre-incubation, one tube of each $\mathrm{Ni}$ treatment was extracted with $35 \mathrm{ml}$ of $1.0 \mathrm{M}$ $\mathrm{KCl}$, and $\mathrm{NH}_{4}^{+}, \mathrm{NO}_{2}{ }^{-} \mathrm{N}$, plus $\mathrm{NO}_{3}{ }^{-}-\mathrm{N}$ were colorimetrically determined using a flow injection auto-analyzer (SKALAR, Holland). To each of the remaining tubes in each treatment, $0.5 \mathrm{ml}$ of $0.044 \mathrm{M}\left(\mathrm{NH}_{4}\right)_{2} \mathrm{SO}_{4}$ was added, and then incubation was continued for 7 days for soils with $\mathrm{pH}>5$ and 28 days for soils with $\mathrm{pH}<5$. The remaining two replicates were analyzed for $\mathrm{NH}_{4}{ }^{+}, \mathrm{NO}_{2}{ }^{-}-\mathrm{N}$, plus $\mathrm{NO}_{3}{ }^{-}-\mathrm{N}$ again as above. Data were used to calculate potential nitrification rate (PNR).

\subsection{Soil solution extraction and analysis}

One replicate from each $\mathrm{Ni}$ treatment was used to extract soil solution at the beginning of SIN assay using the method of Thibault and Sheppard (1992). Soil pH, electrical conductivity (EC), and dissolved organic carbon (DOC) were measured following conventional procedures (Tan 2005). Dissolved elemental concentrations including $\mathrm{Ni}$ in soil solutions were measured either by ICP-AES or by ICP-MS depending on their concentrations in the solutions according to the methods of Khan et al. (2008).

\subsection{Data analysis}

PNR values were calculated from the linear increase in soil $\mathrm{NO}_{3}{ }^{-} \mathrm{-N}$ during the period after ammonium addition (Oorts et al. 2006; Smolders et al. 2001). PNR data was used to generate $\log -\log$ dose-response curves automatically by SigmaPlot 9.0 (SPSS Inc., Chicago, IL, USA) for each soil. $\mathrm{Ni}$ EC50 based on both the measured total Ni concentration (total-Ni-based EC50) and the dissolved Ni concentration in soil solution (solution-Ni-based EC50) was calculated for both the un-leached and leached soils. Some dose-response relationships between PNR and solution Ni cannot be fitted well by any logical model. Hence, solution-Ni-based EC50 values for six un-leached and seven leached soils were absent.

Toxicity thresholds were related to soil properties (e.g., $\mathrm{pH}, \mathrm{CEC}$, clay, OMC, and background $\mathrm{Ni}$ ) with enter or stepwise multiple regressions (SPSS 11.5). The corresponding $\mathrm{pH}$ and concentrations of $\mathrm{Ca}, \mathrm{Mg}, \mathrm{K}, \mathrm{Na}$, and $\mathrm{Zn}$ in soil solutions at Ni EC50 were also estimated by linear interpolation between the measured values (Oorts et al. 2006). The EC50-based free- $\mathrm{Ni}^{2+}$ in soil solution (free$\mathrm{Ni}^{2+}$-based EC50) was calculated based on corresponding solution-Ni-based EC50 and solution composition at EC50 using MINTEQ 2.6 following assumptions by Oorts et al. (2007) and Thakali et al. (2006a). Briefly, the input parameters included solution-Ni-based EC50, and corresponding soil solution $\mathrm{pH}, \mathrm{DOC}, \mathrm{Ca}, \mathrm{Mg}, \mathrm{K}, \mathrm{Na}, \mathrm{Al}$, $\mathrm{Fe}, \mathrm{SO}_{4}{ }^{2-}$, and $\mathrm{Cl}^{-} \cdot \mathrm{SO}_{4}{ }^{2-}$ was calculated from dissolved $\mathrm{S}$, and $\mathrm{Cl}^{-}$was set at a concentration estimated to balance the cations. It was assumed that $70 \%$ of the dissolved organic matter $(\mathrm{DOC} / 2)$ was fulvic acid since most of the soils used in this study were alkaline.

\section{Results}

\subsection{Soil physico-chemistry}

The 17 soils used in this study represent the majority of Chinese soil types and cover a wide range of soil properties in $\mathrm{pH}(4.9-8.9)$, CEC (7.5-33.6 $\left.\mathrm{cmol}^{+} \mathrm{kg}^{-1}\right)$, clay content (10-66\%), background Ni $\left(4.8-118.1 \mathrm{mg} \mathrm{kg}^{-1}\right)$, total Ca $(<0.1-3.5 \%)$, etc. The total concentrations of other potentially toxic elements (e.g., $\mathrm{Cu}, \mathrm{Cr}, \mathrm{Cd}, \mathrm{Zn}, \mathrm{As}$, and $\mathrm{Pb}$; data not shown) in the studied soils generally fall within the normal range of background levels in Chinese soils (Wei et al. 1991).

\section{$3.2 \mathrm{Ni}$ concentration}

Measured total $\mathrm{Ni}$ concentrations $\left(\mathrm{Ni}_{\text {total }}\right)$ were in good agreement with the nominal dose applications in almost all 
treatments. Dissolved Ni concentration [Ni] in un-leached soil solution generally increased with applied $\mathrm{Ni}$ dose exponentially (data not shown). For all Ni treatments, [Ni] ranged from $<0.25$ to $1898.9 \mathrm{mg} \mathrm{L}^{-1}$ (Guangzhou soil) in unleached soil solutions and from $<0.25$ to $627.8 \mathrm{mg} \mathrm{L}^{-1}$ (Guangzhou soil) in leached soil solutions. The un-leached soils can be clearly divided into three groups according to the [Ni] at the highest Ni doses: first is the lower-solution-Ni soils with [Ni] $<100 \mathrm{mg} \mathrm{L}^{-1}$, including Dezhou, Gongzhuling, Shijiazhuang, Yangling (the lowest, $6.31 \mathrm{mg} \mathrm{L}^{-1}$ ), Zhangye, and Zhengzhou soils; second is the highersolution-Ni soils with [Ni] $>380 \mathrm{mg} \mathrm{L}^{-1}$, including Chongqing, Guangzhou (the highest, 1,898.90 $\mathrm{mg} \mathrm{L}^{-1}$ ), Haikou, and Qiyang soils; the others are median-solution-Ni soils with [Ni] ranging from $216.3 \mathrm{mg} \mathrm{L}^{-1}$ (Lingshan soil) to $330.8 \mathrm{mg} \mathrm{L}^{-1}$ (Wulumuqi soil).

Higher Ni amendments heavily impacted the chemical composition of the soil solutions in un-leached treatments (data not shown), leading to increases in $\mathrm{H}^{+}, \mathrm{Ca}^{2+}$, and $\mathrm{Mg}^{2+}$ for all soils. The largest decrease in $\mathrm{pH}$ at the highest $\mathrm{Ni}$ doses occurred in Guangzhou soil (2.20 units) and the lowest decrease occurred in Haikou soil (0.30 units).

Multiple regression showed that up to $78 \%(P=0.005)$ of the variation in $[\mathrm{Ni}]$ in soil solution at highest $\mathrm{Ni}$ doses can be explained by clay content, $\mathrm{CEC}$, and total $\mathrm{Ca}$. No significant correlation was found between $[\mathrm{Ni}]$ in soil solution at highest Ni doses and OMC.

\subsection{Leaching effect on Ni concentration}

Leaching effects on $\mathrm{Ni}_{\text {total }}$ in soils and [Ni] in soil solutions were shown by plotting scatter graphs of the $\mathrm{Ni}_{\text {total }}$ in the un-leached against the leached soils, and [Ni] in the unleached against the leached soil solutions, respectively. To assess the leachablity and thus the sorption behavior of $\mathrm{Ni}$ at the highest $\mathrm{Ni}$ doses, removal rate (RR) is defined as the ratio of the loss of $\mathrm{Ni}_{\text {total }}$ or [Ni] due to leaching to original $\mathrm{Ni}_{\text {total }}$ or [Ni] before leaching, respectively. As shown in Fig. 1a, for total $\mathrm{Ni}$ in soil, leaching effect was not apparent throughout the range of $\mathrm{Ni}$ dosage except for the highest $\mathrm{Ni}$ doses in some soils, like Langfang with the largest RR of $51 \%$. Leaching apparently impacted $[\mathrm{Ni}]$ in soil solutions (see Fig. 1b). At higher [Ni] $\left(>20 \mathrm{mg} \mathrm{L}^{-1}\right),[\mathrm{Ni}]$ was significantly reduced, while at lower [Ni], leaching even increased $[\mathrm{Ni}]$ in some soil solutions. $\mathrm{RR}$ values of $[\mathrm{Ni}]$ at highest Ni doses varied from 5\% (Gongzhuling soil) to 95\% (Dezhou soil).

The other chemical compositions of the soil solutions were also strongly impacted by leaching (data not shown), leading to increase in $\mathrm{pH}$ and reduction in $\mathrm{EC}$ and salinity. For instance, up to $93.0 \%$ of $\mathrm{Ca}$ and $\mathrm{Mg}$ in soil solution at the highest $\mathrm{Ni}$ dose was removed by leaching in Langfang soil.
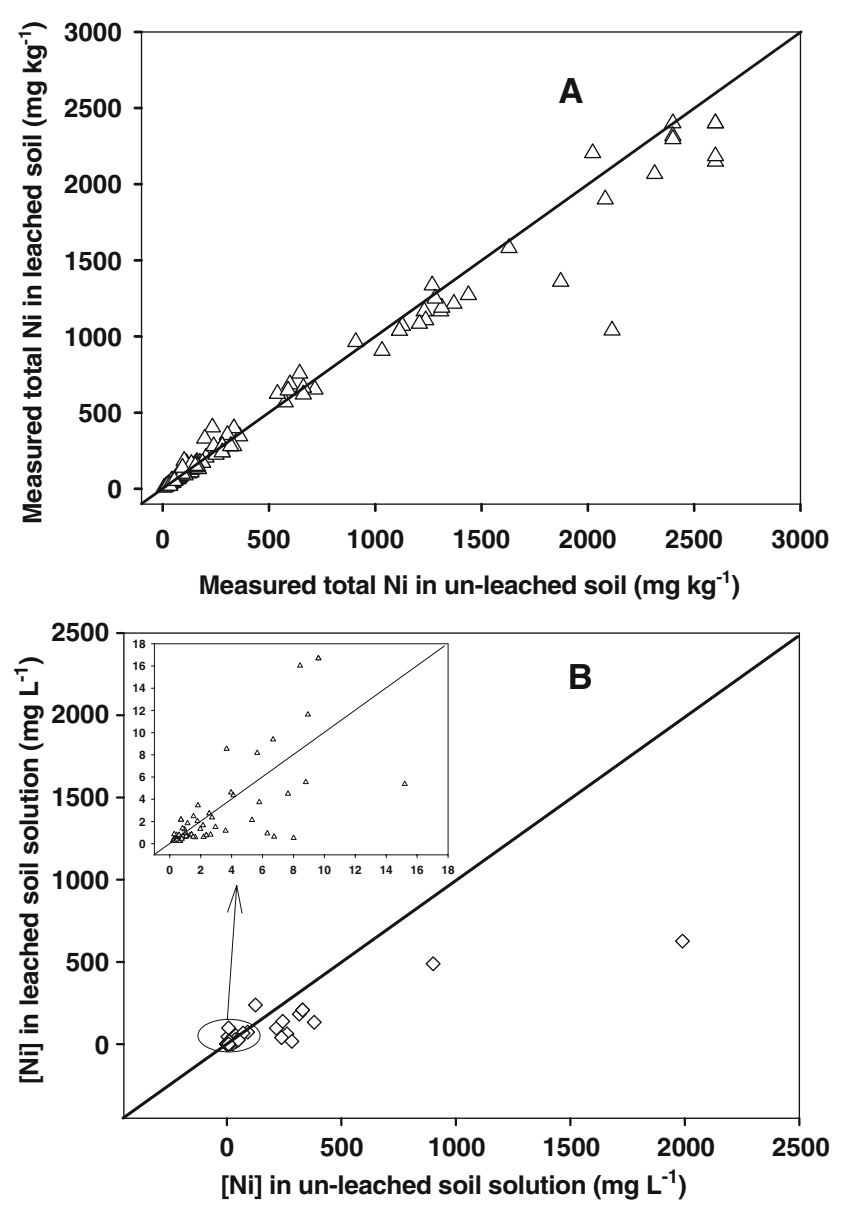

Fig. 1 Leaching effect on the total Ni concentration (a) and dissolved Ni concentration ([Ni]) (b) in the 17 studied soils. The solid line is $1: 1$ line

\section{$3.4 \mathrm{Ni}$ toxicity threshold}

Both the total-Ni-based EC50 (based on $\mathrm{Ni}_{\text {total }}$ ) and solutionNi-based EC50 (based on [Ni] in soil solution) for $\mathrm{Ni}$ in un-leached and leached soils were calculated (Fig. 2). In unleached soils, the total-Ni-based EC50 values ranged from $52.8 \mathrm{mg} \mathrm{kg}^{-1}$ (Hulunber soil) to 2,385.4 $\mathrm{mg} \mathrm{kg}^{-1}$ (Wulumuqi soil), and the available solution-Ni-based EC50 ranged from $0.70 \mathrm{mg} \mathrm{L}^{-1}$ (Jiaxing soil) to $293.35 \mathrm{mg} \mathrm{L}^{-1}$ (Wulumuqi soil). In leached treatments, the total-Ni-based EC50 values ranged from $78.9 \mathrm{mg} \mathrm{kg}^{-1}$ (Qiyang soil) to $2,304.1 \mathrm{mg} \mathrm{kg}^{-1}$ (Zhengzhou soil), and the available solution-Ni-based EC50 ranged from $0.67 \mathrm{mg} \mathrm{L}^{-1}$ (Yangling soil) to $173.37 \mathrm{mg} \mathrm{L}^{-1}$ (Wulumuqi soil).

In order to investigate the protection effect of major cations against $\mathrm{Ni}$ toxicity, the free- $\mathrm{Ni}^{2+}$-based $\mathrm{EC} 50$ values were calculated and related to $\mathrm{pH}, \mathrm{Na}^{+}, \mathrm{K}^{+}, \mathrm{Ca}^{2+}$, and $\mathrm{Mg}^{2+}$ concentration in soil solutions at EC50. Solution-Ni-based EC50 for un-leached soils was not correlated with $\mathrm{pH}, \mathrm{Na}^{+}$, and $\mathrm{K}^{+}$in soil solution at EC50 but significantly correlated with $\mathrm{Ca}^{2+}$ and $\mathrm{Mg}^{2+}$ in soil solution at EC50 (Fig. 3). 

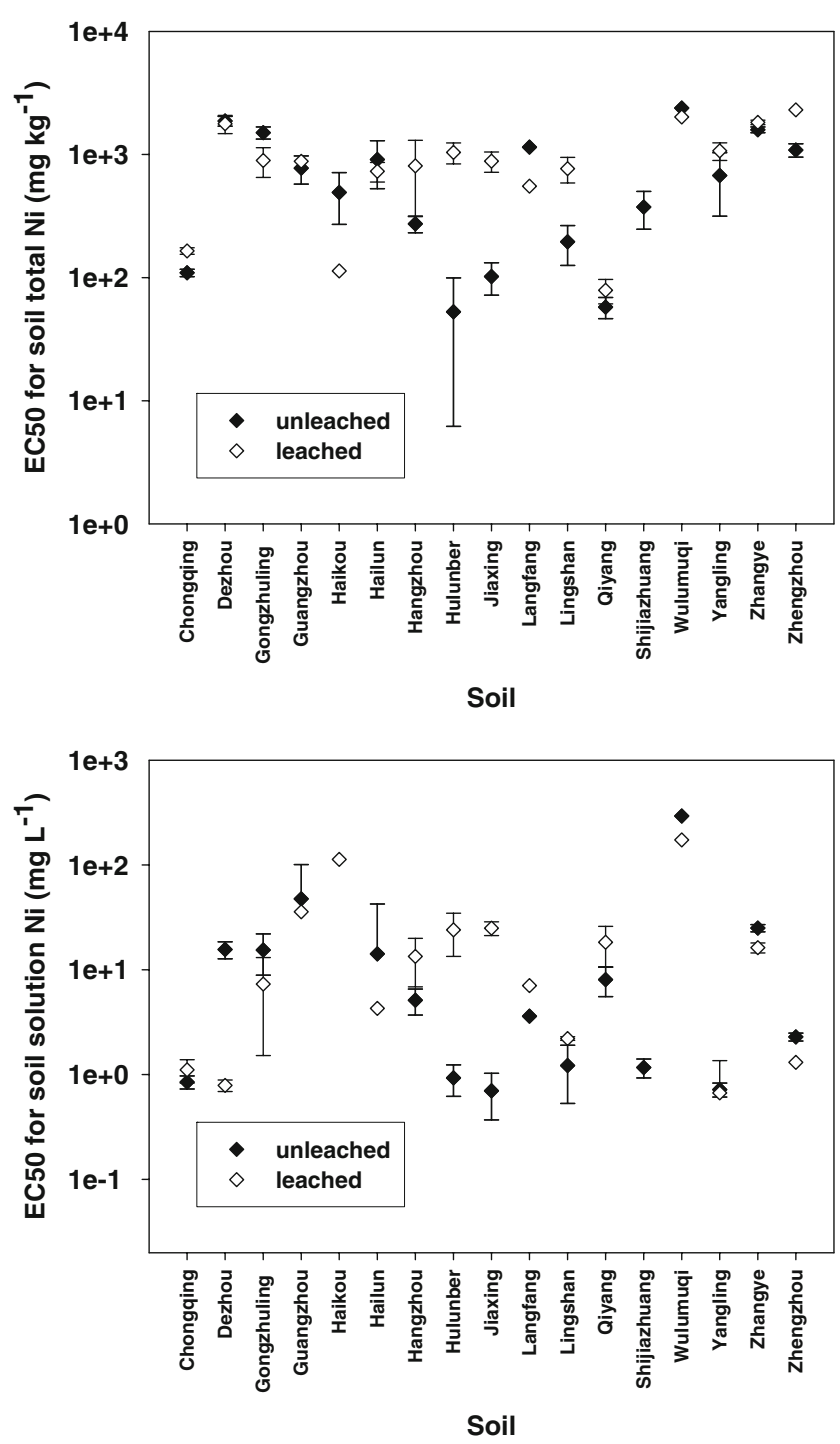

Fig. 2 Total-Ni-based and solution-Ni-based EC50 of Ni in the 17 unleached and leached soils subjected to substrate-induced nitrification assay. Bars represent \pm standard errors of prediction. The absent bars are unacceptable standard errors of prediction

\subsection{Leaching effect on Ni toxicity threshold}

Leaching factor is defined as the ratio of EC50 in leached soil to EC50 in un-leached soil (Oorts et al. 2007). Results showed that leaching inconsistently impacted the EC50 values for $\mathrm{Ni}$ among soils, with leaching factor ranging from 0.2 (Haikou soil) to 19.7 (Hulunber soil) for the totalNi-based EC50 and from 0.1 (Dezhou soil) to 35.7 (Jiaxing soil) for the solution-Ni-based EC50. In addition, significant correlation $\left(R^{2}=0.81, P<0.001\right)$ was found between the leaching factor for total-Ni-based EC50 and EC (Fig. 4), and up to $93 \%(P<0.001)$ of the variation in leaching factor for total-Ni-based EC50 was explained by $\mathrm{EC}$, total $\mathrm{Ca}$, clay content, and CEC. EC was also the controlling factor of leaching factor for solution-Ni-based $\operatorname{EC50}\left(R^{2}=0.31, P=0.031\right)$.

Linear regressions between the Ni EC50 values and the soil parameters were done for both un-leached and leached soils (Table 2). Soil $\mathrm{pH}$ and total $\mathrm{Ca}$ was the best predictor for total-Ni-based EC50 in un-leached soils, while soil pH was the best predictor for solution-Ni-based EC50 in leached soils. Generally, a better prediction for total-Nibased and solution-Ni-based EC50 in leached soils was obtained than those in un-leached soils.

\section{Discussion}

\subsection{Variation and prediction of Ni EC50}

EC50 values varied largely among soils for both the totalNi-based and solution-Ni-based EC50 in un-leached soils. This was in good agreement with Oorts et al. (2006), who found a 90 -fold variation for $\mathrm{Ni}$ based on microbial assays
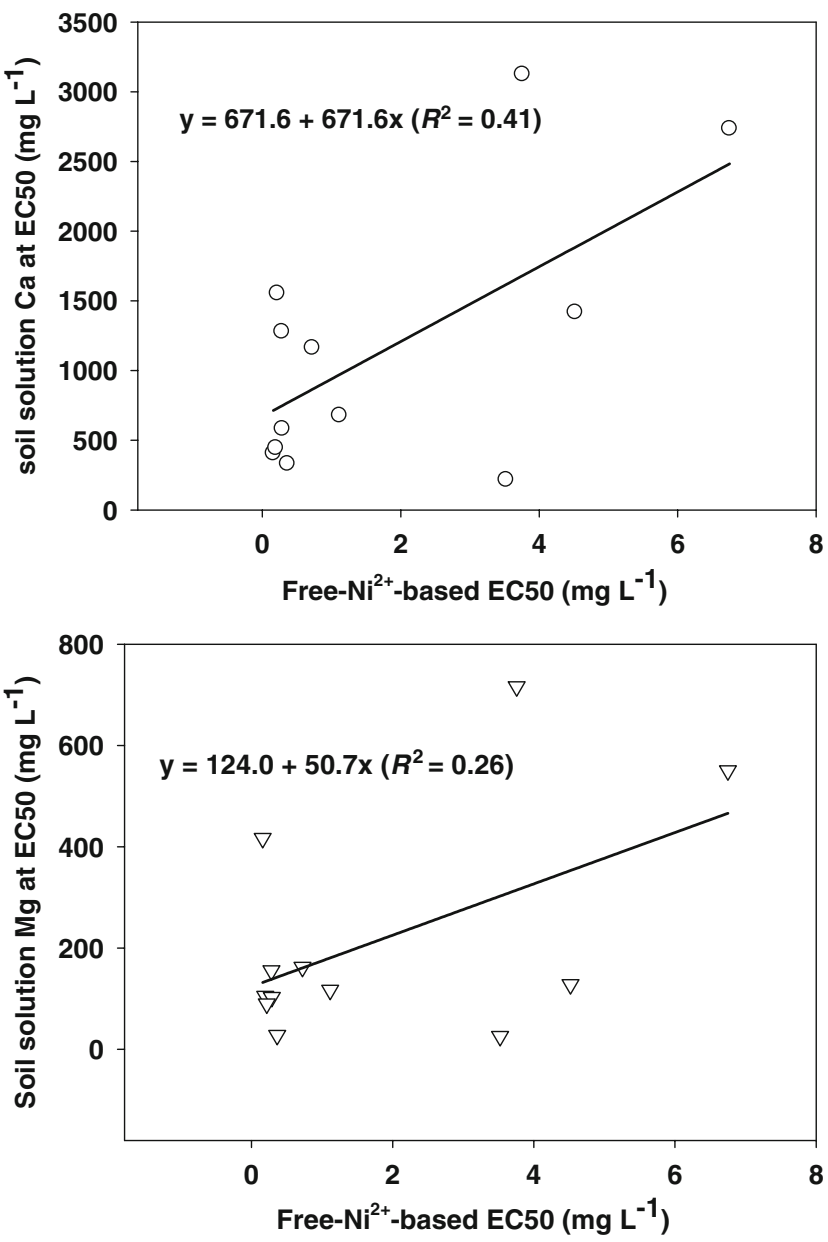

Fig. 3 Regression between free-Ni ${ }^{2+}$-based EC50 and dissolved $\mathrm{Ca}$ and $\mathrm{Mg}$ concentration in soil solution at EC50 


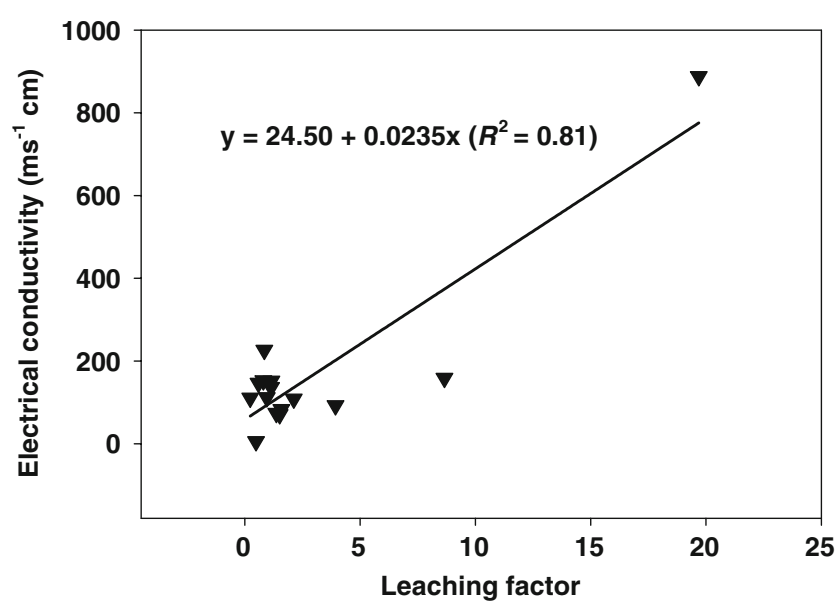

Fig. 4 Positive correlation between leaching factor for total-Ni-based EC50 in soils and soil electrical conductivity

in European soils, and with Rooney et al. (2007), who found a 37-fold variation based on barley root elongation assay and 54-fold variation based on tomato shoot growth assay for $\mathrm{Ni}$ in European soils. These results generally meant that it is more practical to establish a site-specific rather than a single guideline for $\mathrm{Ni}$ in soil. Therefore, efforts were also made to predict the EC50 for $\mathrm{Ni}$ in soils using easily determined soil variables in this study. As shown in Table 2, predicting ability of the equations for $\mathrm{Ni}$ EC50 in leached samples was generally better than that for un-leached samples. With less than three soil variables, a best predicting equation $\left(R^{2}=0.69\right)$ was obtained for $\mathrm{Ni}$ EC50 based on solution Ni for leached soils. The predicting ability of the linear models in this study was generally at the same level as those developed for metals in other studies based on microbial assays (Broos et al. 2007; Oorts et al. 2006; Smolders et al. 2004), however, was obviously less powerful than those based on plant assays (Rooney et al. 2007). A linear model based on barley root elongation assay using the same soils as in present study was able to predict the EC50 within a twofold range of the measured values. Furthermore, involving more variables could increase the predicting ability of the equations for $\mathrm{Ni}$ EC50, indicating that $\mathrm{Ni}$ toxicity to nitrification process in test soils should be controlled by multivariables but not a single variable. Since higher sensitivity of microbial assays generally means higher variability, the prediction of Ni EC50 based on SIN assay may need a further investigation on a larger scale and require comparisons between models for diverse soils from different parts of the world.

For total-Ni-based EC50, it tended to be close after leaching in some soils within the same soil type. For example, the total-Ni-based EC50 was around $860 \mathrm{mg} \mathrm{kg}^{-1}$ in paddy soils from Jiaxing, Hangzhou, and Guangzhou, and around $800 \mathrm{mg} \mathrm{kg}^{-1}$ in black soils from Gongzhuling and Hailun. This implied it may be a possible way to establish soil guidelines for $\mathrm{Ni}$ according to soil type and even soil order instead of using a single predicting model.

Table 2 Multiple regression between Ni EC50 based on substrate-induced nitrification assay in the 17 soils and soil parameters

\begin{tabular}{|c|c|c|c|}
\hline & Regression equation & $R^{2}$ & $P$ \\
\hline \multirow[t]{8}{*}{ Un-leached soils } & Based on total Ni $(n=17)$ & & \\
\hline & $\mathrm{EC} 50=373.1(134.0) \mathrm{Ca}+335.0(220.4)$ & 0.34 & 0.014 \\
\hline & $\log \mathrm{EC} 50=0.3(0.1) \mathrm{pH}+0.8(0.7)$ & 0.33 & 0.016 \\
\hline & $\mathrm{EC} 50=388.3(195.9) \mathrm{pH}+325.9(214.1) \mathrm{Ca}+28.9(13.3)$ clay $-3504.3(1619.6)$ & 0.56 & 0.012 \\
\hline & Based on soil solution $\mathrm{Ni}(n=11)$ & & \\
\hline & No single predictor & - & - \\
\hline & $\mathrm{EC} 50=5.81(2.28) \mathrm{pH}+0.74(0.21)$ clay $-6.91(3.19) \mathrm{OMC}+0.60(0.22) \mathrm{Ni}-64.99(23.55)$ & 0.71 & 0.080 \\
\hline & $\begin{array}{l}\mathrm{EC} 50=11.41(5.32) \mathrm{pH}-7.87(6.56) \mathrm{Ca}-0.45(0.43) \mathrm{CEC}+0.67(0.22) \text { clay }-8.69 \text { (4.53) } \\
\mathrm{OMC}+0.84(0.30) \mathrm{Ni}-92.02(34.30)\end{array}$ & 0.79 & 0.190 \\
\hline \multirow[t]{7}{*}{ Leached soils } & Based on total $\mathrm{Ni}(n=16)$ & & \\
\hline & $\mathrm{EC} 50=402.03(90.65) \mathrm{pH}-2037.61(692.73)$ & 0.58 & 0.001 \\
\hline & $\mathrm{EC} 50=503.67(142.60) \mathrm{pH}+11.04(11.92)$ clay $-3184.45(1420.13)$ & 0.61 & 0.002 \\
\hline & $\begin{array}{l}\mathrm{EC} 50=315.52(170.08) \mathrm{pH}+402.34(199.18) \mathrm{Ca}+0.53(0.61) \mathrm{EC}-19.45(12.45) \text { clay }+ \\
118.77(126.32) \mathrm{OMC}-2828.77(1465.33) \\
\text { Based on soil solution } \mathrm{Ni}(n=10)\end{array}$ & 0.73 & 0.011 \\
\hline & $\mathrm{EC} 50=0.56(0.18)$ clay $-8.29(6.94)$ & 0.48 & 0.013 \\
\hline & $\mathrm{EC} 50=0.61(0.15)$ clay $-0.58(0.23) \mathrm{CEC}+0.001(6.61)$ & 0.69 & 0.006 \\
\hline & $\mathrm{EC} 50=0.88(2.87) \mathrm{pH}+0.73(0.23) \mathrm{clay}-0.59(0.26) \mathrm{CEC}+0.24(0.27) \mathrm{Ni}-16.70(30.01)$ & 0.72 & 0.041 \\
\hline
\end{tabular}

Values in parentheses are standard errors. ' $\mathrm{R}$ ' indicates correlation coefficient and ' $\mathrm{P}$ ' for significant level 
Linear regression (see Table 2) showed that soil $\mathrm{pH}$ and total $\mathrm{Ca}$ governed the Ni toxicity in un-leached soils, which was different from Rooney et al. (2007) who found CEC was the best single predictor for the EC50 of $\mathrm{Ni}$ phytotoxicity in European soils, and was also different from Oorts et al. (2006) who found CEC, background $\mathrm{Ni}$, and clay content were the dominant factors controlling thresholds of Ni microbial toxicity in European soils. This result was not surprising considering the special chemical properties of Chinese soils. Since there is a strong correlation between soil $\mathrm{pH}$ and total $\mathrm{Ca}$ content of the test soils, it is not able to discriminate between an effect of total $\mathrm{Ca}$ and the $\mathrm{pH}$ effects in this study. Basically, soil $\mathrm{pH}$ is a key factor determining the adsorption of metals in soil (Sauve et al. 2000). On the other hand, soil pH is largely controlled by soil chemical compositions and soil texture, particularly $\mathrm{Ca}$ minerals (e.g., calcite and gypsum) and Fe$\mathrm{Al}$ oxides. High-pH soil environment (accordingly high $\mathrm{Ca}$ and low clay content in this study) generally leads to a high retention of soluble Ni added to soil. Therefore, as shown in Table 1, ultisols soils from Haikou and Chongqing containing a large amount $\mathrm{Fe}-\mathrm{Al}$ oxides (expressed as Citrate-dithionite extractable content) were of a $\mathrm{pH}<5.5$ and had a lower total-Ni-based EC50 in un-leached soils. In contrast, inceptisols soils from Dezhou, Langfang, Zhangye, Yangling, and Zhengzhou containing a large amount of Ca minerals were of a $\mathrm{pH}>8.8$ and had a higher total-Nibased EC50 in un-leached soils. In addition, Ca-rich minerals in soil can significantly influence the retention and movement of chemicals and thus their toxicity especially in alkaline environment (Lal and Shukla 2004). That more than $70 \%$ of the test soils in present study were with a $\mathrm{pH}>7$ may be the reason why $\mathrm{Ca}$ but not $\mathrm{Fe}-\mathrm{Al}$ minerals content became the predictor of the total-Ni-based EC50 in un-leached soils. Such mechanisms have also been shown in previous studies which found liming (Everhart et al. 2006) and amendment of Ca-rich clay mineral (Usman et al. 2005) greatly decreased the Ni bioavailability in soils. Furthermore, high total $\mathrm{Ca}$ generally means high $\mathrm{Ca}^{2+}$ in soil solution (Fig. 5), and thus may impact the Ni toxicity through competitive binding on biological membranes. However, when comparing correlations with soil properties between the present study and Oorts et al. (2006) or Rooney et al. (2007), it should be noted that the CEC in these previous studies was measured at $\mathrm{pH}$ of the soil and at low ionic strength, resulting in an effective CEC compared to a potential CEC in the present study. The differences in CEC analysis can strongly affect the resulting correlations. Therefore, whether effective CEC also plays important role in predicting the Ni EC50 in test soils in present study remains to be investigated.

The variation in total-Ni-based EC50 was not explained by solution-Ni-based EC50 in un-leached soils, since a

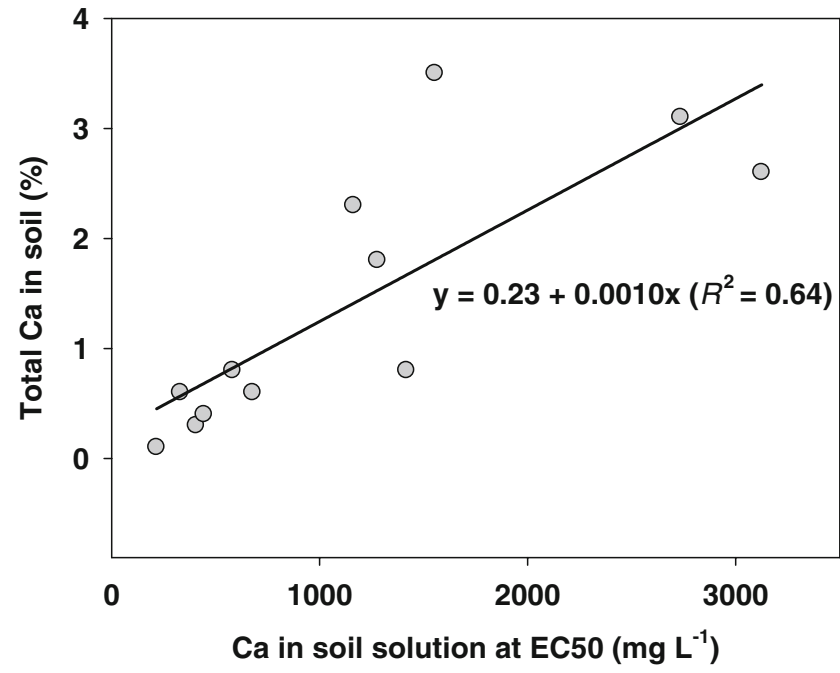

Fig. 5 Positive correlation between total $\mathrm{Ca}$ in soil and dissolved $\mathrm{Ca}$ concentration in soil solutions at EC50

larger variation in solution-Ni-based EC50 was found in this study. This was generally consistent with previous studies and made it impossible to explain the variation in metal toxicity among soils by using free metal-ion activity alone (Broos et al. 2007; Oorts et al. 2006). Free-Ni ${ }^{2+}$ based EC50 was not involved in the prediction for Ni EC50 in this study, since it was calculated based on many assumptions and not an easily determined parameter. Furthermore, many studies revealed a remarkable diversity of DOC in binding capacity from different soils (Kolts et al., 2008) and free ion activity theory has been challenged for $\mathrm{Ni}$ in soil (Sarathy and Allen 2005). A strong correlation between dissolve Ni in soil solution and calculated free- $\mathrm{Ni}^{2+}$ in soil solution was found in present and previous studies (Oorts et al. 2007; Fig. 6), with the percentage of calculated free- $\mathrm{Ni}^{2+}$ in dissolved $\mathrm{Ni}$ at EC50 being around $30 \%$. This result implied free- $\mathrm{Ni}^{2+}$ in soil solution might be not sensitive as $\mathrm{Cu}$ to soil solution chemistry and controlled mainly by dissolved $\mathrm{Ni}$ concentration. However, this conclusion was based on results by model prediction (MINTEQ 2.6 or WHAM 6) and required confirmation by mechanistic study.

Competitive binding of $\mathrm{Ca}^{2+}$ and $\mathrm{Mg}^{2+}$ on biological membranes against free $\mathrm{Ni}^{2+}$ was indicated by the significant correlations between free- $\mathrm{Ni}^{2+}$-based EC50 and dissolved $\mathrm{Ca}$ and $\mathrm{Mg}$ concentrations at EC50 (see Fig. 3). This may largely but not completely explain the variation in solution-Ni-based EC50 according to the concept of TBLM (Lock et al. 2007a, b; Simpson and Batley 2007; Thakali et al. 2006a, b). In addition, the competitive effect of $\mathrm{H}^{+}$on $\mathrm{Ni}^{2+}$ toxicity was not observed in this study. This is consistent with the studies for Ni toxicity by Lock et al. (2007b) and also for some other metals (de Schamphelaere 


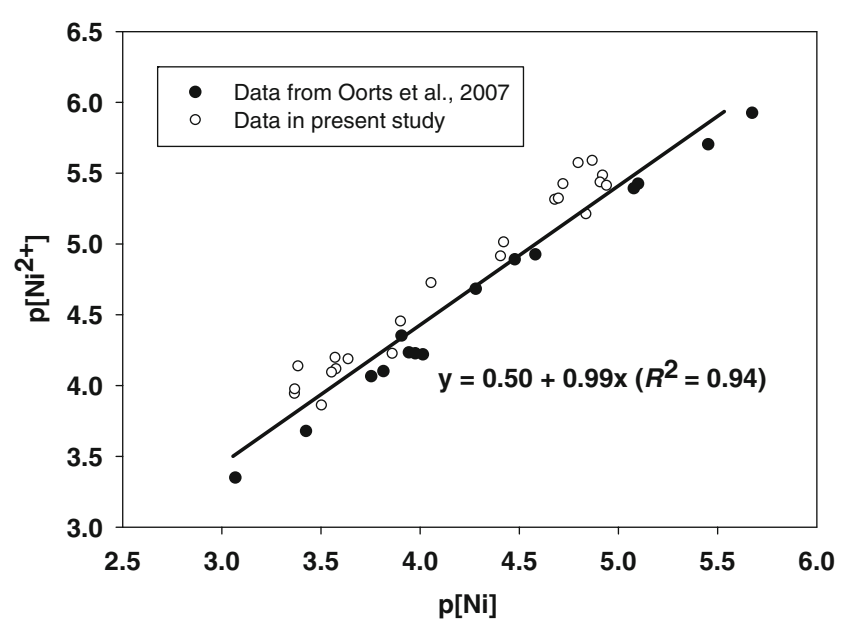

Fig. 6 Strong correlation between $-\lg$ dissolved Ni in soil solution (p [Ni]) and $-\mathrm{lg}$ calculated free $\mathrm{Ni}^{2+}$ in soil solution $\left(\mathrm{p}\left[\mathrm{Ni}^{2+}\right]\right)$ in present study and previous study

and Janssen 2002; Heijerick et al. 2002b; Lock et al. 2007a). However, more previous studies have observed a significant correlation between EC50 and $\mathrm{pH}$ at EC50 (Erickson et al. 1996; Heijerick et al. 2002a; Parker et al. 1998; Thakali et al. 2006a, b; Voigt et al. 2006). Hence, incorporation of proton competition into the concept of BLM remains to be justified (Wang et al. 2009).

\subsection{Leaching effect on Ni concentration and EC50 in soils}

Leaching heavily impacted soil solution compositions and $\mathrm{Ni}$ EC50 values. The impacts on both the solution chemistry and Ni EC50, however, were apparently inconsistent among soils (see Figs. 1 and 2).

As suggested by some authors (Lock et al. 2006; Oorts et al. 2007), leaching obviously removed the "excess" salts including [Ni] at higher Ni doses (see Fig. 1). This may increase the ecological relevance of the toxicity assay for soil metals, since the loss of "excess" salts including [Ni] by leaching simulated the natural leaching and aging process of metals in soil (Keller et al. 2002; Kiikkila et al. 2002; Nemeth and Kadar 2005) and reduced the potential toxicity of the counterions (Bongers et al. 2004). Loss of free metal ion in soil solution induced by leaching was also observed for $\mathrm{Ni}$ (Oorts et al. 2007) and for Pb (Lock et al. 2006) in European soils. In addition, the significant increase of the correlation between total-Ni-based EC50 and original soil $\mathrm{pH}$ in leached soils (see Table 2), together with the correlation between solution-Ni-based EC50 and soil clay content, might point to a return of the soil solution chemistry to a $\mathrm{pH}$-controlled equilibrium from the state of overloading of soluble $\mathrm{Ni}$ in some soils. As indicated by the analysis of the variation in [Ni] at largest $\mathrm{Ni}$ doses among soils and also previous studies (Agbenin and Atin 2003; Yu et al. 2002), the adsorption mechanisms of soluble metals added to soil might be quite different at high Ni doses and could not simply be explained by the soil $\mathrm{pH}$, since the immediate increase in $[\mathrm{Ni}]$ and $\left[\mathrm{H}^{+}\right]$may remarkably exceed the maximum adsorption for $\mathrm{Ni}$ in some soils especially for those with low $\mathrm{pH}$ and high salinity. Thus, removal of excess $\mathrm{Ni}^{2+}$ might increase the predictability of Ni EC50 with soil parameters. Taken together, leaching increased the ecological relevance of the SIN assay for Ni.

Although leaching caused an obvious loss of [Ni] at higher Ni doses in all soils, the impacts of leaching on both the total-Ni-based EC50 and the solution-Ni-based EC50 were inconsistent among soils as indicated by the leaching factor. Generally, the inconsistent effect of leaching on the total-Ni-based EC50 can be attributed to the inconsistent impact of leaching on [Ni] at low Ni doses (see Fig. 1) and the two counteracting effects of leaching on the soil solution compositions (Oorts et al. 2007). Although it was concluded that leaching can decrease the free ion concentration of a given metal in soil solution, an increase in [Ni] at low Ni doses in Haikou, Qiyang, Gongzhuling, and Hailun soils was observed, implying a complicated influence of leaching on soil solution at low Ni doses. This may partially explain why these soils had a leaching factor of $<1$ for total-Ni-based EC50. Moreover, loss of free $\mathrm{Ni}^{2+}$, which can positively increase the total-Ni-based EC50, was simultaneously accompanied by the loss of a large amount of protective cations, which may negatively decrease the total-Ni-based EC50. This may also contribute to the variation in leaching factor for total-Ni-based EC50.

For solution-Ni-based EC50, the inconsistent impact of leaching cannot be simply explained by the loss of major cations in soil solution. Generally, as observed by Oorts et al. (2007), in all of the three test soils, loss of protective cations in soil solution may decrease solution-Ni-based EC50. In this study, however, leaching factor was found to be $>1$ in four soils, although the solution-Ni-based EC50 were decreased by leaching in most soils. One possible reason for this could be that high salinity induced by spiking was significantly toxic to nitrification process, and leaching alleviated such toxicity. Yet, this explanation refers to the nature of the indigenous nitrifying communities and remains to be shown, since in most soils, leaching factor was $<1$ for solution-Ni-based EC50, and the incorporation of the toxicity of counterions seemed not necessary.

The original purpose of introducing leaching to bioassays is to remove the excess counterions which can exert a direct toxic effect or an indirect effect by raising the salinity. However, as natural process, the partition of the soluble metal added to soils, together with the covarying solution chemistry, are controlled by soil properties (Alumaa et al. 2002; Ponizovsky et al. 2008; Yu et al. 2002), while the artificial leaching may disturb the entire 
soil solution except for counterions and generate temporary thermodynamic equilibriums which might be largely determined by leaching process (e.g., the duration of leaching, the composition of leaching solution, and the total volume of leaching solution). Hence, to what extent the leaching is sufficient, that is, whether the leaching effect following a conventional leaching protocol is comparable among soils and whether the leaching effect can be predicted with soil parameters, are critically important. Leaching factor for the total-Ni-based EC50 was well predicted by EC, total Ca, clay content, and CEC in this study. All of the factors determining the leaching factor for both total-Ni-based EC50 and solution-Ni-based EC50 are related to the immediate adsorption capacity of soil and thus the leachability of Ni added as soluble salt to soil. Particularly, EC is an indicator for soil salinity (Rhoades and Corwin 1990; Rhoades et al. 1989), and salinity can largely impact the retention of soluble metals added to soil through competitive adsorption and salt effect enhancing the solubility of the added salt. Therefore, in Hulunber soil with highest EC high leachability of dissolved $\mathrm{Ni}$ in soil solution may be responsible for the highest leaching factor. However, it should be stressed that for soils with low leaching factors, EC effect was not significant, and $\mathrm{Ca}$ and clay content together with CEC may play an important role. In addition, similar with the study by Lock et al. (2006), conductivities of more than $4 \mathrm{mS}^{-1} \mathrm{~cm}$ were observed in the highest Ni treatments of five soils. Furthermore, RR of [Ni] at highest Ni doses varied largely among soils, and no correlation was found between RR values and soil properties. This probably implied that the leaching effect on the [Ni] was controlled by the leaching process itself but not soil properties. Taken together, these results highlight the need for further quantitative investigation of leaching effect on the Ni partition in soils before leaching is used as a standard protocol in toxicity assays.

\section{Conclusions}

In conclusion, large variation was found for the total-Nibased EC50 in un-leached Chinese soils. The variation in total-Ni-based EC50 was not explained by the solution-Nibased EC50 since a larger variation in the solution-Nibased EC50 was observed. This may make it difficult to establish a single guideline for $\mathrm{Ni}$ in Chinese soils and, alternatively, site-specific guidelines should be more practical. Linear models based on soil variables were tried to predict both total-Ni-based and solution-Ni-based EC50. Soil $\mathrm{pH}$, clay content and total $\mathrm{Ca}$ content were found to be important factors affecting Ni EC50. Protective effects of $\mathrm{Ca}^{2+}$ and $\mathrm{Mg}^{2+}$ but not $\mathrm{H}^{+}, \mathrm{Na}^{+}$, or $\mathrm{K}^{+}$at $\mathrm{EC} 50$ against free $\mathrm{Ni}^{2+}$ toxicity were found. In addition, leaching heavily impacted soil solution compositions and both the total-Nibased EC50 and the solution-Ni-based EC50 in the studied soils, but its impacts were inconsistent among soils. To some extent, leaching increased the ecological relevance of the SIN assay for $\mathrm{Ni}$, considering that the predictability of the total-Ni-based EC50 in leached soils increased, and the variation in leaching factor among soils was largely explained by soil properties. However, a need still exits to quantitatively investigate the leaching effect on soil solution chemistry before leaching is used as a standard protocol in toxicity assays.

Acknowledgements The authors would like to thank the financial support of the International Copper Association, Rio Tinto Limited, the Nickel Producers Environmental Research Association, the Natural Science Foundation of China (project 40620120436 and 30671204), Knowledge Innovation Project of the Chinese Academy of Sciences (No.KSCX2-YW-N-41-05), and Tianjin Specific Fund for Scientific and Technologic innovation (No. 06FZZDSH00900). We thank the CSIRO and Bo Li for their help to analyze soil properties and leaching treatments. We also thank Dr. Chris Schlekat for his critical comments.

\section{References}

Agbenin JO, Atin AM (2003) Copper sorption characteristics and activity in a savanna acid soil from Nigeria. Water Air Soil Pollut 150(1-4):43-58

Allen HE, Lin Y-Q, Di Toro DM (2008) Ecotoxicity of Ni in soil. Mineral Mag 72:367-371

Alumaa P, Kirso U, Petersell V, Steinnes E (2002) Sorption of toxic heavy metals to soil. Int J Hyg Environ Health 204(5-6):375-376

Berton RS, Pires AMM, de Andrade SAL, de Abreu CA, Ambrosano EJ, da Silveira APD (2006) Nickel toxicity in common bean plants and effects on soil microbiota. Pesqui Agropecu Bras 41 (8):1305-1312

Bongers M, Rusch B, Van Gestel CA (2004) The effect of counterion and percolation on the toxicity of lead for the springtail Folsomia candida in soil. Environ Toxicol Chem 23(1):195-199

Broos K, Mertens J, Smolders E (2005) Toxicity of heavy metals in soil assessed with various soil microbial and plant growth assays: as comparative study. Environ Toxicol Chem 24(3):634-640

Broos K, Warne MSJ, Heemsbergen DA, Stevens D, Barnes MB, Correll RL, McLaughlin MJ (2007) Soil factors controlling the toxicity of copper and zinc to microbial processes in Australian soils. Environ Toxicol Chem 26(4):583-590

de Schamphelaere KA, Janssen CR (2002) A biotic ligand model predicting acute copper toxicity for Daphnia magna: the effects of calcium, magnesium, sodium, potassium, and $\mathrm{pH}$. Environ Sci Technol 36(1):48-54

Erickson RJ, Benoit DA, Mattson VR, Nelson HP, Leonard EN (1996) The effects of water chemistry on the toxicity of copper to fathead minnows. Environ Toxicol Chem 15(2):181-193

Everhart JL, McNear D Jr, Peltier E, van der Lelie D, Chaney RL, Sparks DL (2006) Assessing nickel bioavailability in smeltercontaminated soils. Sci Total Environ 367(2-3):732-744

Fargasova A (2008) Phytotoxicity of chromium and nickel. Ecol Chem Eng S 15(3):335-348

Fernandez MD, Cagigal E, Vega MM, Urzelai A, Babin M, Pro J, Tarazona JV (2005) Ecological risk assessment of contaminated 
soils through direct toxicity assessment. Ecotoxicol Environ Saf 62(2):174-184

Giller KE, Witter E, McGrath SP (1998) Toxicity of heavy metals to microorganisms and microbial processes in agricultural soil: a review. Soil Biol Biochem 30:1389-1414

Heijerick DG, De Schamphelaere KA, Janssen CR (2002a) Biotic ligand model development predicting $\mathrm{Zn}$ toxicity to the alga Pseudokirchneriella subcapitata: possibilities and limitations. Comp Biochem Physiol C Toxicol Pharmacol 133(1-2):207-218

Heijerick DG, De Schamphelaere KA, Janssen CR (2002b) Predicting acute zinc toxicity for Daphnia magna as a function of key water chemistry characteristics: development and validation of a biotic ligand model. Environ Toxicol Chem 21(6):1309-1315

Keller C, McGrath SP, Dunham SJ (2002) Heavy metals in the environment - trace metal leaching through a soil-grassland system after sewage sludge application. J Environ Qual 31 (5): $1550-1560$

Khan S, Cao Q, Zheng YM, Huang YZ, Zhu YG (2008) Health risks of heavy metals in contaminated soils and food crops irrigated with wastewater in Beijing, China. Environ Pollut 152(3):686-692

Kiikkila O, Derome J, Brugger T, Uhlig C, Fritze H (2002) Copper mobility and toxicity of soil percolation water to bacteria in a metal polluted forest soil. Plant Soil 238:273-280

Kolts JM, Brooks ML, Cantrell BD, Boese CJ, Bell RA, Meyer JS (2008) Dissolved fraction of standard laboratory cladoceran food alters toxicity of waterborne silver to Ceriodaphnia dubia. Environ Toxicol Chem 27(6):1426-1434

Lal R, Shukla MK (2004) Principles of soil physics. Marcel Dekker, Inc., New York, pp 42-48

Lock K, Janssen CR (2002) Ecotoxicity of nickel to Eisenia fetida, Enchytraeus albidus and Folsomia candida. Chemosphere 46 (2): $197-200$

Lock K, Waegeneers N, Smolders E, Criel P, Van Eeckhout H, Janssen CR (2006) Effect of leaching and aging on the bioavailability of lead to the springtail Folsomia candida. Environ Toxicol Chem 25(8):2006-2010

Lock K, De Schamphelaere KA, Becaus S, Criel P, Van Eeckhout H, Janssen CR (2007a) Development and validation of a terrestrial biotic ligand model predicting the effect of cobalt on root growth of barley (Hordeum vulgare). Environ Pollut 147(3):626-633

Lock K, Van Eeckhout H, De Schamphelaere KAC, Criel P, Janssen CR (2007b) Development of a biotic ligand model (BLM) predicting nickel toxicity to barley (Hordeum vulgare). Chemosphere 66(7):1346-1352

Lofts S, Spurgeon DJ, Svendsen C, Tipping E (2004) Deriving soil critical limits for $\mathrm{Cu}, \mathrm{Zn}, \mathrm{Cd}$, and $\mathrm{Ph}$ : a method based on free ion concentrations. Environ Sci Technol 38(13):3623-3631

Marriott EE, Wander MM (2006) Total and labile soil organic matter in organic and conventional farming systems. Soil Sci Soc Am J 70(3):950-959

Matejovic I (1997) Determination of carbon and nitrogen in samples of various soils by the dry combustion. Commun Soil Sci Plant Anal 28(17-18):1499-1511

Nemeth T, Kadar I (2005) Leaching of microelement contaminants: a long-term field study. Z Naturforsch, C, Biosci 60(3-4):260-264

Nriagu JO, Pacyna JM (1988) Quantitative assessment of worldwide contamination of air, water and soils by trace metals. Nature 333 (6169):134-139

Oorts K, Ghesquiere U, Swinnen K, Smolders E (2006) Soil properties affecting the toxicity of $\mathrm{CuCl} 2$ and $\mathrm{NiCl} 2$ for soil microbial processes in freshly spiked soils. Environ Toxicol Chem 25(3):836-844

Oorts K, Ghesquiere U, Smolders E (2007) Leaching and aging decrease nickel toxicity to soil microbial processes in soils freshly spiked with nickel chloride. Environ Toxicol Chem 26 (6): $1130-1138$
Paquin PR, Gorsuch JW, Apte S, Batley GE, Bowles KC, Campbell PG, Delos CG, Di Toro DM, Dwyer RL, Galvez F (2002) The biotic ligand model: a historical overview. Comp Biochem Physiol C Toxicol Pharmacol 133(1-2):30-35

Parker DR, Pedler JF, Thomason DN, Li HY (1998) Alleviation of copper rhizotoxicity by calcium and magnesium at defined free metal-ion activities. Soil Sci Soc Am J 62(4):965-972

Ponizovsky AA, Allen HE, Ackerman AJ (2008) Effect of field aging on nickel concentration in soil solutions. Commun Soil Sci Plant Anal 39(3-4):510-523

Rhoades JD, Corwin DL (1990) Soil electrical-conductivity-effects of soil properties and application to soil-salinity appraisal. Commun Soil Sci Plant Anal 21(11-12):837-860

Rhoades JD, Manteghi NA, Shouse PJ, Alves WJ (1989) Soil electrical-conductivity and soil-salinity - new formulations and calibrations. Soil Sci Soc Am J 53(2):433-439

Rooney CP, Zhao FJ, McGrath SP (2007) Phytotoxicity of nickel in a range of European soils: influence of soil properties, Ni solubility and speciation. Environ Pollut 145(2):596-605

Sarathy V, Allen HE (2005) Copper complexation by dissolved organic matter from surface water and wastewater effluent. Ecotoxicol Environ Saf 61(3):337-344

Sauve S, Hendershot W, Allen HE (2000) Solid-solution partitioning of metals in contaminated soils: dependence on $\mathrm{pH}$, total metal burden, and organic matter. Environ Sci Technol 34(7):1125-1131

Simpson SL, Batley GE (2007) Predicting metal toxicity in sediments: a critique of current approaches. Integr Environ Assess Manag 3 (1):18-31

Smolders E, Brans K, Coppens F, Merckx R (2001) Potential nitrification rate as a tool for screening toxicity in metalcontaminated soils. Environ Toxicol Chem 20(11):2469-2474

Smolders E, Buekers J, Oliver I, McLaughlin MJ (2004) Soil properties affecting toxicity of zinc to soil microbial properties in laboratory-spiked and field-contaminated soils. Environ Toxicol Chem 23(11):2633-2640

Tan KH (2005) Soil sampling, preparation, and analysis. Taylor \& Francis Group, Boca Raton

Thakali S, Allen HE, Di Toro DM, Ponizovsky AA, Rooney CP, Zhao FJ, McGrath SP (2006a) A terrestrial biotic ligand model. 1. Development and application to $\mathrm{Cu}$ and $\mathrm{Ni}$ toxicities to barley root elongation in soils. Environ Sci Technol 40(22):7085-7093

Thakali S, Allen HE, Di Toro DM, Ponizovsky AA, Rooney CP, Zhao FJ, McGrath SP, Criel P, Van Eeckhout H, Janssen CR (2006b) Terrestrial biotic ligand model. 2. Application to $\mathrm{Ni}$ and $\mathrm{Cu}$ toxicities to plants, invertebrates, and microbes in soil. Environ Sci Technol 40(22):7094-7100

Thibault DH, Sheppard MI (1992) A disposable system for soil porewater extraction by centrifugation. Commun Soil Sci Plant Anal 23(13-14):1629-1641

Usman A, Kuzyakov Y, Stahr K (2005) Effect of clay minerals on immobilization of heavy metals and microbial activity in a sewage sludge-contaminated soil. J Soils Sediments 5(4):245-252

Voigt A, Hendershot WH, Sunahara GI (2006) Rhizotoxicity of cadmium and copper in soil extracts. Environ Toxicol Chem 25(3):692-701

Wang XD, Ma YB, Hua L, McLaughlin MJ (2009) Identification of hydroxyl copper toxicity to barley (Hordeum vulgare) root elongation in solution culture. Environ Toxicol Chem 28(3):662-667

Wei FS, Chen JS, Wu YY, Zheng CJ (1991) Elemental background values in Chinese soils. Environ Sci 12:12-19 (in Chinese)

Yu S, He ZL, Huang CY, Chen GC, Calvert DV (2002) Adsorptiondesorption behavior of copper at contaminated levels in red soils from China. J Environ Qual 31(4):1129-1136

Zarcinas BA, McLaughlin MJ, Smart MK (1996) The effect of acid digestion technique on the performance of nebulization systems used in inductively coupled plasma spectrometry. Commun Soil Sci Plant Anal 27(5-8):1331-1354 